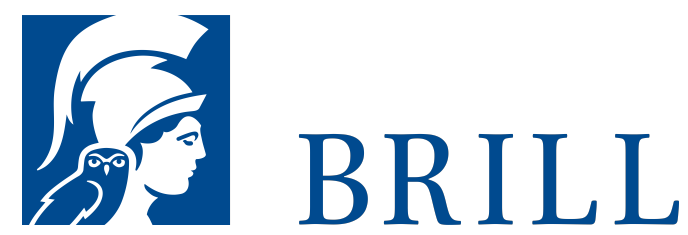

\section{Nanoscience and Nanotechnology opening the Way to New Studies in Other Areas of Science}

\section{Author: Herbert Gleiter}

Die Nordrhein-Westfälische Akademie der Wissenschaften und der Künste ist eine Vereinigung der führenden Forscherinnen und Forscher des Landes. Sie wurde 1970 als Nachfolgeeinrichtung der Arbeitsgemeinschaft für Forschung des Landes Nordrhein-Westfalen gegründet. Die Akademie ist in drei wissenschaftliche Klassen für Geisteswissenschaften, für Naturwissenschaften und Medizin sowie für Ingenieur- und Wirtschaftswissenschaften und in eine Klasse der Künste gegliedert.

Mit Publikationen zu den wissenschaftlichen Vorträgen in den Klassensitzungen, zu öffentlichen Veranstaltungen und Symposien will die Akademie die Fach- und allgemeine Öffentlichkeit über die Arbeiten der Akademie und ihrer Forschungsstellen informieren.

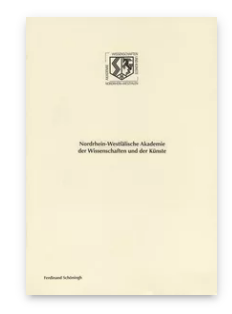

Pages: 28 Seiten

Language:

German

Subjects:

History of

Science, History

Publisher: Brill |

Schöningh

Series:

Nordrhein Westfälische

Akademie der

Wissenschafte - Ingenieurund

Wirtschaftswissenschaften, Volume: 29

E-Book (PDF)

Released online:

$29 \mathrm{Jan} 2020$

ISBN: 978-3-

657-76878-3

List price

USD $\$ 28.00$

Paperback

Publication date:

22 Jul 2009

ISBN: 978-3-

506-76878-о

List price

USD $\$ 28.00$ 
For more information see brill.com

Order information: Order online at brill.com +44330 333 0049 | customerservices@brill.com Submission information: brill.com/authors

Titles published by Brill | Fink, Brill | mentis or Brill | Schöningh: +49(o)715413279216| brill@brocom.de 